UDK $630 * 272+632(497.11)=111$

UDK 635.054+632(497.11) $=111$

Original scientific paper

\title{
EVALUATION OF THE CONDITION OF DENDROLOGICAL SPECIES IN ACADEMIC PARK IN BELGRADE
}

\author{
Katarina MLADENOVIĆ ${ }^{1}$, Ivan MILENKOVIĆ ${ }^{1}$, Tatjana ĆIRKOVIĆ- \\ MITROVIĆ $^{1}$, Ljiljana BRAŠANAC-BOSANAC ${ }^{1}$
}

\begin{abstract}
This paper presents the results of the conducted evaluation of the health condition and seed yield of the dendrological species in Academic Park in Belgrade. Both scores for each individual tree and average scores for all trees within each plant genus under observation were analyzed. The health condition of 126 trees belonging 19 genera was examined while the seed yield was assessed for the total of 132 trees. The best as-is health and physiological condition was observed in the following species: nettle trees, honey locusts, pagoda trees, cedars and individual ginkgo and tulip poplar trees. Horse chestnuts, eastern black walnuts and birch trees proved less resilient to biotic and abiotic damages. Japanese pagoda trees had the best seed yield. There were no significant differences in fruit bearing between the two years of research, although there were different scores at the individual level. Of all deciduous species recorded, which were prevailing, about 60\% had very good seed yield in both years of monitoring, while some $20 \%$ of trees bore no fruits. Coniferous trees had higher fruit-bearing score in 2015 (47.4\%) than in 2016 (43.0\%), whereas about 10\% of all conifers bore no fruit at all.
\end{abstract}

Key words: damages, dendrological species, fungi, insects, mites, seed yield, park, Belgrade.

\footnotetext{
${ }^{1}$ Dr Katarina Mladenović, Dr Ivan Milenković, Dr Tatjana Ćirković-Mitrović, Dr Ljiljana Brašanac-Bosanac, Institute of Forestry, Kneza Viseslava 3, Belgrade, Serbia

Acknowledgments:This paper is a result of research carried out within the Project "Development of Technological Methods in Forestry in order to Attain Optimal Forest Cover" (TR 31070, led by Dr. Ljubinko Rakonjac) financed by the Ministry of Education, Science and Technological Development of the Republic of Serbia and "Morphological-Anatomic and Physiological Changes in Dendrological Species in Belgrade Parks as Indicators of the State of the Environment" (led by Dr. Ljubinko Rakonjac, coordinated by Dr. Baranislava Batos), financed by the City of Belgrade, City Administration, Secretariat for Environmental Protection.
} 


\section{OCENA STANJA DRVENASTIH BILJNIH VRSTA U AKADEMSKOM PARKU U BEOGRADU}

Izvod: $U$ radu je prikazan rezultat izvršenog ocenjivanja zdravstvenog stanja $i$ uroda semena drvenastih biljnih vrsta u Akademskom parku u Beogradu. Analizirane su ocene za svako pojedinačno stablo kao i srednje ocene svih stabala za svaki posmatrani biljni rod. Pregled zdravstvenog stanja je obuhvatio 126 stabala iz 19 rodova, a ocenjen je urod na 132 stabla. Utvrđeno je da su najboljeg zatečenog zdravstvenog stanja i fiziološke kondicije sledeće vrste: koprivić, gledičija, sofore i kedrovi i pojedinačna stabla ginka $i$ liriodendrona. Manje otporna na biotička $i$ abiotička oštećenja pokazala su se stabla: divljeg kestena, crnog oraha i breze. Najbolji urod imala su stabla sofore. Plodonošenje u obe godine istraživanja nije se bitno razlikovalo, mada je bilo individualnih razlika u oceni plodonošenja. Kod najviše zastupljenih svih evidentiranih lišćarskih vrsta, oko 60\%, urod u bio vrlo dobar u obe godine praćenja ove pojave, a nije plodonosilo oko $20 \%$ stabala.. Kod četinarskih vrsta stabala sa najvišom ocenom plodonošenja bilo je 2015. godine 47,4\%, a 2016. godine 43,0\%. Nije plodonosilo oko 10\% stabala četinarskih vrsta. park, Beograd.

Ključne reči: oštećenja, drvenaste biljne vrste, gljive, insekti, grinje, urod semena,

\section{INTRODUCTION}

There are 65 public parks in Belgrade and they are mostly situated in the city's most beautiful parts. The total area of Belgrade's parks covers about 385 hectares. In comparison to the developed urban areas, the parks in Belgrade are small and unevenly distributed. Academic (Student) Park is located in the old Belgrade downtown area, in front of the Belgrade University Rectorate, at Student Square, between Vasina Street and the square. The area of Academic Park covers 1.45 hectares. Since 2007 the park has been categorized as a significant natural asset with third degree protection regime set up.

Predominant among the tree species in the park are older chestnut, ginkgo, plane and English oak trees. There is a protected small-leaved lime tree as well.

Changes in the environmental habitat factors have adverse impact on the physiological and hence health condition of the dendrological plant species. Due to the reduced general resilience, plants are more susceptible to the attacks of fungal phytopathogens causing rot and plant diseases and harmful insects and mites. In urban areas, where tree species are more exposed to effects of numerous both abiotic and biotic factors (higher air temperatures, lower soil moisture, air pollution, higher soil salinity, human influences, fungi, insects, mites, etc.), crown condition enables assessment of their overall condition and represents a valid measure for their health evaluation. Crown condition, as an indicator of biotic and anthropogenic impacts on the condition of trees, is viewed through different classes of defoliation and discoloration.

Damages may be various and often species-specific or specific for groups of fungi, insects and mites, although they are most commonly non-specific and resulting from several different causes (Agrios 2005; Karadžić 2010). Proper identification of the causes of damage to the urban greenery is of the outmost 
significance for prevention of symptom spread and preservation of its longevity and aesthetic value. In addition to mechanical damages, pests and fungal pathogens may produce toxic effects that will be manifest both in foliage and other plant organs, which results in reduced fitness and more or less reduced decorativeness. Attacked leaves display damaged stomatal complex, higher transpiration activity, loss of chlorophyll and the like, which may give rise to early defoliation, discoloration and even desiccation and early foliage fall (Agrios 2005). Foliage damage is manifest through changes in color, gallfly and blister mite infestations, leaf curls, bud hypertrophy and other malformations (Karadžić 2010; Mihajlović 2008). Due to the synergic or simultaneous attack of harmful insects and fungal pathogen infections, shoots are slow in growth and die out, branches rot and die out, and crowns become more transparent and show a typical "dieback" degradation.

Park trees on the other hand can have more favorable growth and development owing to more frequent inspections and better care and protection undertaken by the competent institutions. Such trees have larger crowns and are exposed to more light, and, as they are supplied larger quantities of nutrients, they have more frequent and plentiful yield. Time needed for fruit maturation in forest tree and shrub species depends on the genus or species, and within the same species on the habitat, in particular microclimatic characteristics of the habitat during fruit maturation.

\section{MATERIALS AND METHODS}

During vegetation in the years 2015/16 all trees in Academic Park in Belgrade were examined in order to evaluate the general condition of the tree species. The examination of the health of trees involved detection of mechanical, phytopathological, entomological and acarological damages to the tree crowns, tree trunks and root collar zone.

Fieldwork was conducted twice during a single vegetation period, in spring and in summer. Biotic and abiotic damages were identified in all trees. For evaluation of the as-is health condition of trees and identification of any health impairing factors, visual assessments of health condition and of assimilation area loss and discoloration were made for the trees under observation. In June and July defoliation was assessed, while discoloration was inspected in the observed trees in August, applying ICP Forests methodology (Anonymous, 2006; 2010).

Visual assessment of the health of trees was provided for all trees under observation according to the following scale:

Score 5 - Healthy tree (without visible symptoms of damage to the foliage, trunk and branches, or with insignificant damage);

Score 4 - Tree with minor damage (rare and random damage to the foliage, trunk and branches, with a small number of dry branches);

Score 3 - Tree with significant damage (presence of damage to the foliage, trunk and branches with possibility of recovery, tip burns, rot in trunk and/or branches);

Score 2 - Tree dying out (significantly reduced leaf assimilation area, progressive rot in trees and branches, poses a public safety issue) 
Score 1 - Dead tree.

Young, newly planted trees were exempt from the evaluation of the health condition, with remarks recorded on any abiotic and/or biotic damages present.

The recorded harmful causes of decay were determined directly during fieldwork wherever possible. Samples of leaves, conifer needles, shoots necrotic tissues, rotten tree parts as well as those of wood-rotting fungus fruiting bodies were collected and processed in the Phytopathological and Entomological Laboratory of the Institute of Forestry.

Leaf samples were observed in the laboratory under binocular and light microscopes to determine the presence of pathogen fungus fruiting bodies and spore-bearing structures, causes of leaf flecking and spotting and other changes in leaves. Samples of conifer needles, shoots and tree branches were treated in the laboratory as follows: they were first sterilized on the surface in $70 \%$ ethyl alcohol or $4 \%$ sodium hypochlorite solution, then rinsed in sterile distilled water and thereafter dried on sterile paper tissue. Parts thereof were then dissected using a scalpel sterilized in $70 \%$ ethyl alcohol and open flame, and then placed on the malt extract agar (MEA) and potato dextrose agar (PDA) media prepared according to the recipe by Booth (1971). Culture incubation was conducted in daylight or in dark, as appropriate, at temperatures ranging from 22 to $25^{\circ} \mathrm{C}$. The objective of isolation was to obtain pure cultures of pathogen fungi in order to properly identify and verify causes of damage and decay in trees. For identification of species observed in the preparations under the light microscope and in pure cultures after isolation, different publications containing identification keys and species characteristics were used (Agrios (2005); Alexopoulos et al., (1996); Barnett and Hunter (1998); Breitenbach and Kränzlin (1986); Černy (1989); Davidson et al., (1938); Gilbertson (1979); Hagara et al., (2012); Karadžić (2010); Karadžić et al., (2014); Karadžić and Milenković (2014, 2015); Murrill (1903, 1908); Overholts (1953); Pegler and Waterston (1968); Ryvarden and Johansen (1980); Sutton (1980); Stalpers (1978); Wagner and Fischer (2002) and others).

From the trees displaying symptoms typical for infections with the species from the genus Phytophthora (e.g. top-to-bottom die-out, reduced crown density, trunk and root collar necrosis, necrosis and damage to the larger roots and rot and loss of the fine roots) samples of necrotic tree tissues and of soil containing fine roots were collected. The tree tissue samples were rinsed in sterile distilled water and placed on selective nutrient medium prepared under the methodology of Jung et al., (1996, 2000) Jung (2009). Isolation from the soli was made using the baiting method (Jung et. al., 1996, 2000; Milenković 2015). Upon appearance of first hyphae from the inoculum of the tree and leaf tissues, these were transferred to the fresh carrot agar (CA) medium (Jung and Nechwatal 2008). The obtained isolates were identified and confirmed as belonging to the Phytophthora genus by developing both sexual and asexual structures in non-sterile soil solution under the methodology of Erwin and Ribeiro (1996) their observation under the light microscope with a magnification of $\times 400$. For the same purposes morphological keys presented in Erwin and Ribeiro (1996), Stamps et al. (1990), and recently issued publications with descriptions of new species were used.

Plant materials were collected for identification of pests during vegetation by random sampling or based on the symptoms displayed. Leaves, buds, blossoms, 
twigs and the like were sampled and packed into polyethylene bags and later stored in the refrigerator at the temperature of $5^{\circ} \mathrm{C}$ until processing. Pests were identified microscopically or directly on the field based on the symptoms present and insects hunt out in different development stages. Insects were hunted out directly with fingers, using brushes, catchers or by means of an aspirator. Mites were separated from the plant material using a stereo microscope. After separation, eriophyid mites were directly immersed into Heinz medium whereas tetranychidae were immersed into the mixture of ethanol and lactic acid for light maceration (Evans \& Browing 1955) so that they are ready for further preparation process. Petri dishes had been incubated in a heater at the temperature of $35^{\circ} \mathrm{C}$ for several days or held at the room temperature for up to a few months. Hoyer's medium (Baker \& Wharton 1964) was used for preparation of the permanent tetranychidae specimens. The permanent specimens were observed through a phase-contrast light microscope using oil immersion technique (Leica DMLS). For insect and mite identification purposes appropriate taxonomy literature and keys were used (Amrine et al., 2003; Baker et al., 1996; Domes 1998; Keifer 1938-1979; Malandraki et al., 2004; Nalepa 1910; Petanović 1988a, b; Shi \& Boczek 2000; Baker \& Tuttle 1994; Mitrofanov et al., 1987; Prichard \& Baker, 1955; Reeves, 1963; Rota, 1962; SmithMeyer 1987; Begljarov 1981; Chant 1959; DeMoraes et al., 1986; Demite et al., 2014; Karg 1993; Moraes et al., 2004; Alford 1995; Johnson \& Lyon 1991; Maceljski 1986, 2002; Mihajlović 2007, 2008; PetrovićObradović 2003; Tanasijević and Simova-Tošić 1987; Strous \& Winter 2000).

In the course of the two-year field and laboratory research of the seed yield of dendrological species in Academic Park, the total of 132 trees were examined and scored. Individual trees were scored for seed yield for all deciduous and conifer species. Analyses of the seed yield and its volume were performed using the adapted Kaper scale for forecasting seed yield within a stand (Table 1) (Stilinović, 1985, Isajev et. al., 1998).

Table 1. Yield scoring scale

\begin{tabular}{|lc|c|}
\hline \multicolumn{2}{|c|}{$\begin{array}{c}\text { Category of yield } \\
\text { volume - score }\end{array}$} & Quantitative yield volume parameters \\
\hline $\mathbf{0}$ & - & No fruit \\
\hline $\mathbf{1}$ & Very poor & Insignificant number of fruits in trees \\
\hline $\mathbf{2}$ & Poor & Small number of fruits in trees \\
\hline $\mathbf{3}$ & Medium & More observable fruits in trees \\
\hline $\mathbf{4}$ & Good & Sufficient fruits in trees \\
\hline $\mathbf{5}$ & Very good & High volume of fruits in trees \\
\hline
\end{tabular}

\section{RESULTS AND DISCUSSION}

\subsection{Evaluation of health condition}

The total of 126 trees belonging to 19 genera were examined. The largest in number is the park under observation were young pear trees (Pirus spp.), of which 22 were examined, then plane trees (Platanus spp.), of which 20 were examined and cedars (Cedrus spp.) and Japanese pagoda trees (Sophora japonica), 
of which 18 trees were examined per respective species. Other species had small number of trees in the park. All trees examined classified into genera are presented in Table 2.

Table 2. Total number of trees examined in Academic Park

\begin{tabular}{|c|c|}
\hline Genus & No. of trees \\
\hline Acer & 1 \\
\hline Aesculus & 12 \\
\hline Cedrus & 18 \\
\hline Betula & 1 \\
\hline Catalpa & 1 \\
\hline Celtis & 1 \\
\hline Fraxinus & 1 \\
\hline Ginkgo & 1 \\
\hline Gleditsia & 7 \\
\hline Juglans & 2 \\
\hline Koelreuteria & 4 \\
\hline Liriodendron & 1 \\
\hline Pinus & 1 \\
\hline Pirus & 22 \\
\hline Platanus & 20 \\
\hline Prunus & 3 \\
\hline Quercus & 4 \\
\hline Sophora & 18 \\
\hline Tilia & 8 \\
\hline TOTAL & $\mathbf{1 2 6}$ \\
\hline & \\
\hline & \\
\hline
\end{tabular}

In a single Acer pseudoplatanus L. examined, the trunk displayed mechanical injuries, which were appropriately treated, and individual dry branches were identified so that the tree was assessed as a tree with minor damage without considerable defoliation and discoloration.

In twelve trees Aesculus hippocastanum L. mechanical injuries of the root collar and trunk were identified and open cancer wounds in certain cases, as well as necrosis with dark exudate, typical for Phytophthora spp. In addition, in certain instances, dry branches and carpophores of rot fungus Phellinus spp. were observed. Top-to-bottom drying was perceived as well as leaf flecks caused by Guignardia aesculi (Pk.) Stew. and the presence of horse chestnut leaf miner Cameraria ochridella Desch. \& Dimić. The health condition of horse chestnut trees was assigned the average score of 3.4 - trees with significant damage. Medium discoloration and moderate defoliation were identified in the foliage. Three young trees were excluded from the assessment. 
The young Betula verrucosa Erhr tree displayed mechanical injury of the root collar and trunk and dry branches. Its health condition was hence assigned score 3.0 - a tree with significant damage, low discoloration and severe defoliation.

In a single Catalpa bignonioides Walter tree random dry branches and mechanical damage to the root collar were observed so that it was assessed as a tree with minor damage (4.0) without defoliation and discoloration perceived.

Of eighteen Cedrus atlantica (Endl.) Mann. ex Carr. trees examined, some exhibited mechanical injuries, which were adequately treated. Some closed cancer wounds and sap exuding were also identified. The average score assigned for health condition of cedars in the park was 4.3 with no discoloration and weak defoliation observed.

A single Celtis australis L. tree received the highest score (5.0) with no defoliation or discoloration identified.

A single Fraxinus ornus L. tree had mechanical damage and was assigned score 4.0 as no discoloration or defoliation were identified. score 4.0.

A single Ginkgo biloba L. tree had random dry branches and was assigned

Seven Gleditsia triacanthos L. trees were examined. Some of them had mechanical injuries in the root collar area and trunk. The average score for the health condition of this group of trees was 4.4 as no defoliation or discoloration were observed.

In the two Juglans nigra L. trees mechanical injuries were recorded in the trunk and branches as well as random dry branches. The average score for black walnut trees equals 3.0 with no defoliation and low discoloration observed.

Four Koelreuteria paniculata Laxm. trees examined scored 4.0 on the average, showing slight defoliation and no discoloration.

In a single young Liriodendron tulipifera $\mathrm{L}$. tree there were mechanical injuries in the trunk and it therefore scored 4.0.

Twenty-two young Pirus spp. trees were examined, some of them exhibiting mechanical injuries to the branches, which were adequately treated.

In a single Pinus nigra Arnold examined, random dry branches were observed with no defoliation and low discoloration identified, caused by fungus Lophodermium pinastri (Schrad) Chev. The score assigned for health condition was 4.0.

The examination covered 20 Platanus $\times$ acerifolia (Aiton) Willd. trees, 16 of which were young plants. In some of the older trees there were mechanical injuries in the root collar zone and branches. Presence of the fungal pathogen Apiognomonia veneta (Sacc. \& Speg.) Höhn. causing leaf flecks along the nerves and anthracnose was observed, as well as of the sycamore lace bug Corytucha ciliata Say. The average score of 4.0 was assigned to the plane trees since slight defoliation and low to medium discoloration were perceived.

In the three Prunus cerasifera var. pissardii (Carr.) Koehne trees examined, foliage chlorosis and mechanical injuries treated and healed were perceived so that these scored 4.8 on the average for health condition given that no defoliation and low discoloration were identified.

In four oaks (Quercus robur L.) examined, two of them young, the presence of powdery mildew Erysiphe alphitoides (Grif. \&Maubl.) Br. \& Takam. 
(sin. Microsphaera alphitoides Grif. \& Maubl.), chlorosis and mechanical damage to the trunk and root collar were observed. Older trees scored 4.0 on the average given their slight defoliation and moderate discoloration.

Eighteen Sophora japonica (L.) trees were subject to examination. In certain trees, the root collar, trunk and branches showed mechanical damages. The average score for the health condition of this group of trees was 4.8 since no defoliation or discoloration were identified.

Seven Tilia parvifolia Ehrh. trees and one T. tomentosa Moench. tree were examined. In small-leaved lime trees, lime tree aphid Eucallipterus tiliae (L.), planthopper Metcalfa pruinosa (Say) and spider mite Tetranychus urticae Koch. were observed. In some instances, tree trunks and root collars display mechanical damages. This group of trees scored 4.2 on the average, with no defoliation and low discoloration identified.

The average health condition scores for all species examined in the park are provided in Table 3 below.

Table 3. The average health condition scores for all trees in Academic Park

\begin{tabular}{|c|c|}
\hline Genus & Score \\
\hline Acer & 4.0 \\
\hline Aesculus & 3.4 \\
\hline Betula & 3.0 \\
\hline Catalpa & 4.0 \\
\hline Cedrus. & 4.3 \\
\hline Celtis & 5.0 \\
\hline Fraxinus & 4.0 \\
\hline Ginkgo & 4.0 \\
\hline Gleditsia & 4.4 \\
\hline Juglans & 3.0 \\
\hline Koelreuteria & 4.0 \\
\hline Liriodendron & 4.0 \\
\hline Pinus & 4.0 \\
\hline Pirus & $/$ \\
\hline Platanus & 4.0 \\
\hline Prunus & 4.8 \\
\hline Quercus & 4.0 \\
\hline Sophora & 4.8 \\
\hline Tilia & 4.2 \\
\hline TOTAL & $\mathbf{4 . 0}$ \\
\hline
\end{tabular}

Based on the examination performed on all the trees (Table 2) in the park under observation, it is clear that the species with the best as-is health state and physiological condition were: nettle trees, honey locusts, pagoda trees, cedars and individual ginkgo and tulip poplar trees. Horse chestnuts, eastern black walnuts and birch trees proved less resilient to biotic and abiotic damages.

\subsection{Volume of seed yield}

The total of 132 trees were recorded in Academic Park, of which 85 are fruit-bearing trees. The percentages of trees per seed yield volume category monitored over two years of research (2015-2016), are presented in Graph 1. There were no significant differences year on year in evaluation of seed yield volume. 


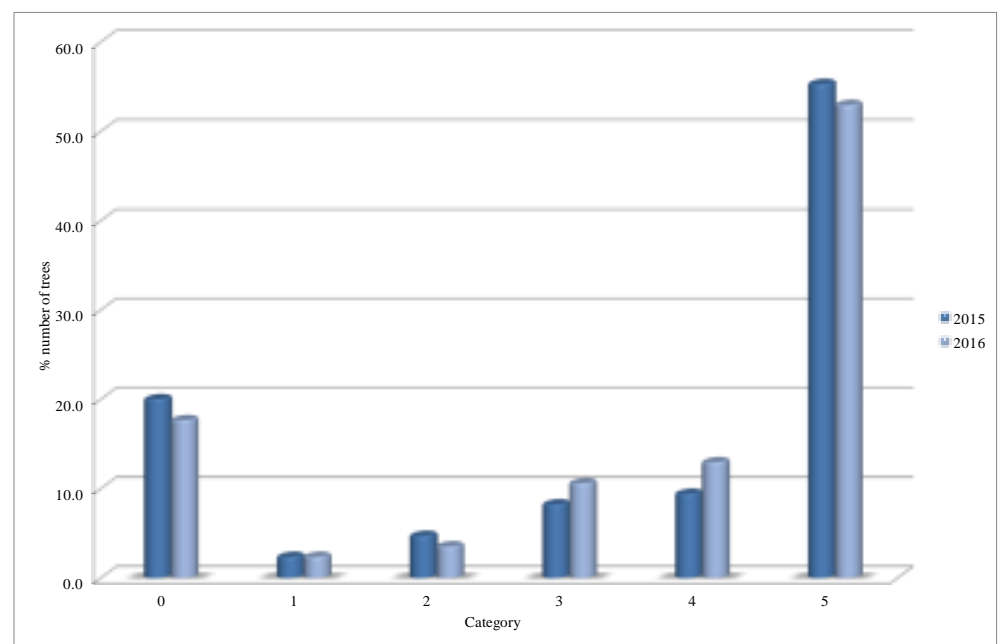

Graph 1. Percentages of trees per seed yield volume category in Academic Park

Japanese pagoda tree (Sophora japonica L.) represents a deciduous species with the largest number of fruit-bearing trees -18 - in the park. Of these 18 trees, 17 were ranked within the highest-score category, while only one scored 2 and 1 in 2015 and 2016, respectively, when it had a small/insignificant number of fruits (Graph 2a).

Among conifers, the Atlas cedars (Cedrus atlantica (Endl.) Manetti ex Carrière), were the largest in number with the total of 17 trees. In each year of research 9 trees had high volume yields, while score 4 was assigned to three trees in 2015 and thereafter to four trees of this species in 2016 (Graph 2b).



a) Sophora japonica

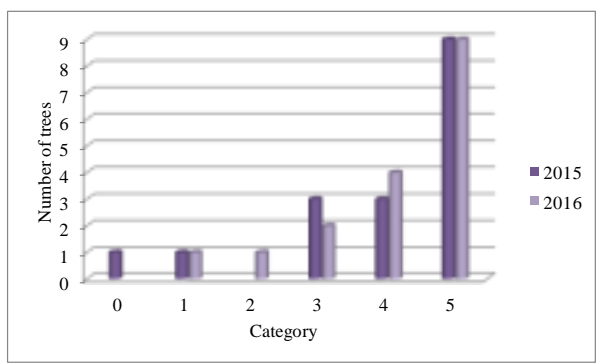

b) Cedrus atlantica

Graph 2. Percentages of the predominant (in number of trees) deciduous and conifer species per seed yield volume category

Out of five plane trees (Platanus $x$ acerifolia (Aiton) Willd.) four were fruit-bearing, three with high volume yield. Percentage of trees that scored 2 in 2015 decreased while that of trees with score 3 in 2016increased.

A single sycamore maple tree (Acer pseudoplatanus L.), had a high volume yield over the period under observation as well as a silver lime tree, so these two were classified into category 5 - very good. 
A single black pine tree (Pinus nigra Arnold) scored 4 both in 2015 and

Table 4. Percentages of all deciduous and conifer tree species per yield volume category

\begin{tabular}{|c|c|c|c|c|c|c|c|c|c|c|c|c|}
\hline & \multicolumn{12}{|c|}{ Category of yield volume - score } \\
\hline & $\mathbf{0}$ & 1 & 2 & 3 & 4 & 5 & $\mathbf{0}$ & 1 & 2 & 3 & 4 & 5 \\
\hline & \multicolumn{6}{|c|}{$\%$ in 2015} & \multicolumn{6}{|c|}{$\%$ in 2016} \\
\hline Decic & 21.2 & 3.0 & 6.1 & 6.1 & 6.1 & 57.6 & 21.2 & 3.0 & 3.0 & 9.1 & 3.0 & 60.6 \\
\hline Conifer & 10.5 & 5.3 & 0.0 & 15.8 & 21.1 & 47.4 & 10.5 & 0.0 & 5.3 & 10.5 & 316 & 42.1 \\
\hline
\end{tabular}

For all deciduous species observed in terms of their yield volume, it may be deduced that for all deciduous species with large number of trees the yield was very good (category 5) - about $60 \%$ - in both years of research. About $21 \%$ of deciduous trees bore no fruits. In conifer species, $47.4 \%$ of trees had the highest score (category 5) in 2015, while in 2016 their share decreased to $43.0 \%$. About $10 \%$ of conifer trees bore not fruits at all (Table 4 ).

\section{CONCLUSIONS}

Based on the phytopathological, entomological and acarological research performed, it was concluded that the species subject to analyses differ in health condition. Certain species such as nettle trees, honey locusts, pagoda trees, cedars, ginkgo and tulip poplar trees displayed rather high resilience, good health and physiological condition in contrast to horse chestnuts, eastern black walnuts and birch trees, which, in the park under observation, proved more sensitive to both biotic and abiotic agents. In Academic Park horse chestnut turned out to be the most sensitive species and hence most susceptible to the attacks of pathogens and insects.

Assessment and comparison of damages caused by biotic agents reveal that, in the park under observation, damages caused by fungal phytopathogens are more substantial than those caused by pest insects and mites.

Identified insect and mite species observed in larger populations during the research, had no significant impact on the development of the plant species assessed. They affected the aesthetics of the plants, caused physiological weakening of the plants, their discoloration defoliation, which, over prolonged periods, along with other adverse agents and influences within the urban environment, may result in plant drying.

A large number of trees with small or larger mechanical injuries were recorded in the park, with most of these injuries treated in adequate manner. However, in certain instances, wounds were direct entryway for penetration and further development of fungal pathogens, in particular wood rot fungi.

No significant differences were identified in the trees examined year on year and season on season $(2015,2016)$ in terms of their health. The environment, primarily through the impact of climatic factors, affects the presence of phytopathological and entomological causes of damage, yet several years of research may be required for more clarified conclusions on this matter. 
Protection measures and care undertaken on a regular annual basis in Academic Park have contributed to decreased pest populations and pathogenicity of pathogens, resulting in the high average score for health condition of the entire park.

There were no significant differences in fruit bearing between the two years of research, although there were different scores at the individual level. For all deciduous species observed in terms of their yield volume, it may be deduced that for all deciduous species with large number of trees the yield was very good (category 5) - about $60 \%$ - in both years of research. About $21 \%$ of deciduous trees bore no fruits. In conifer species, $47.4 \%$ of trees had the highest score (category 5) in 2015, while in 2016 their share decreased to $43.0 \%$. About $10 \%$ of conifer trees bore not fruits at all. Japanese pagoda tree (Sophora japonica L.) represents a species with the largest number of fruit-bearing trees in the park. Among conifers, the Atlas cedars (Cedrus atlantica (Endl.) Manetti ex Carrière). Evaluation of the fruit-bearing is largely dependent on the species and genus, so that the percentage share (number) of both trees and the species, i.e., diversity of the species, has had an effect on the evaluation of the fruit-bearing.

For proper interpretation of the results obtained regarding the impact of adverse factors (both biotic and abiotic) on the general health condition and defoliation and discoloration intensity, further observation and assessment of the health of tree species are necessary so that long-term prognoses can be made.

\section{REFERENCES}

Agrios G. N. (2005): Plant Pathology (Fifth Edition). Elsevier Academic Press, Burlington, San Diego, London: 1-922.

Alexopoulos C. J., Mims C. W., Blackwell M. (1996): Introductory Mycology (Fourth Edition). John Wiley and Sons, Inc., New York, Chichester, Brisbane, Toronto, Singapore, 1-868.

Alford, D., (1995): A Colour Atlas of Ornamental Trees, Shrubs and Flowers. Manson Publishing, London.

Amrine, J. W. JR., T. A. Stasny, C. H. W. Fletchmann (2003): Revised keys to world genera of Eriophyoidea (Acari: Prostigmata). Indira Publishing House, West Bloomfield, Michigan, USA, p 244.

Anonymus, (2010): Visual assessment of crown condition and damaging agents -Manual on methods and criteria for harmonized sampling, assessment, monitoring and analysis of the effects of air pollution on forests, Part IV, International Co-operative Programme on the Assessment and Monitoring of Air Pollution Effects on Forests, Hamburg.

Anonymus, (2006): Visual assessment of crown condition -Manual on methods and criteria for harmonized sampling, assessment, monitoring and analysis of the effects of air pollution on forests, International Co-operative Programme on the Assessment and Monitoring of Air Pollution Effects on Forests, Hamburg. 
Baker, E.W., Kono, J., Amrine, J.W. Jr, Delfinado-Baker, M., Stasny, T. (1996): Eriophyoid Mites of the United States. Indira Publishing House. West Bloomfield, Michigan, USA.

Baker, E.W., Tuttle, D.M. (1994): A guide to the spider mites (Tetranychidae) of the United States. Indira Publishing House, pp. 347.

Barnett H. L., Hunter B. B. (1998): Illustrated Genera of Imperfect Fungi (Fourth Edition). APS Press, St. Paul, Minnesota: 1-218.

Begljarov, G.A. (1981): Key for identification of the predacious mites Phytoseiidae (Parasitiformes, Phytoseiidae) in the fauna of the USSR. Information Bulletin EPS IOBC, 3, pp. 141.

Booth C. (1971): Methods in microbiology. Vol. 4, Academic Press, London, 1-795.

Breitenbach J., Kränzlin F. (1986): Champignons de Suisse. Tome 2. Edition Mycologia, CH-6000 Lucerne 9, 1-412.

Chant D. A. (1959): Phytoseiid mites (Acarina:Phytoseiidae). Part I. Bionomics of seven species in Southeastern England. 1-44 pp.

Černy A. (1989): Parazitické Drevokazné houby. Vydalo ministerstvo lesniho a vodniho hospodárstvi a drevozpracujiciho prumyslu ČSR ve Statnim zemedelskem nakladatelstvi v Praze, 1-100.

Davidson R.W., Campbell W.A., Blaisdell J.D. (1938): Differentiation of wood-decaying fungi by their reaction on gallic or tannic acid medium. Journal of Agricultural Research, Vol.57, no.9, Washington, 683-695.

Demite, P.R., de Moraes, G.J., McMurtry, J.A., Denmark, H.A., Castilho, R. de C. (2016.): Phytoseiidae Database. www.lea.esalq.usp.br/phytoseiidae.

De Moraes G. J., McMurtry J. A., Denmark H. A., Campos C. B. (2004): A revised catalog of the mite family Phytoseiidae. Zootaxa 434: 1-494.

De Moraes, G. J., J. A. McMurtry, H. A. Denmark (1986): A catalog of the family Phytoseiidae. References to taxonomy, synonymy, distribution and habitat. EMBRAPA, Brasilia, Brazil. 353 pp.

Domes, R., (1998): A new species of the genus Anthocoptes (Phyllocoptinae: Eriophyidae) on Juglans regia L. Acarologia 39 (1): 69-71.

Erwin D. C., Ribeiro O.K. (1996): Phytophthora diseases worldwide. APS Press, American Phytopathological Society, St. Paul, Minnesota.

Evans, G.O., Browning, E, (1955): Techniques for the preparation of mites for study. Ann. Mag, Nat. Hist., 8(12): 631-635.

Gilbertson R. L. (1979): The Genus Phellinus (Aphyllophorales: Hymenochaetaceae) in Western North America. Mycotaxon 9, 51-89, 51-89. 
Hagara L., Antonin V., Baier J. (2012): Velký Atlas Hub. Vydalo Ottovo Nakladatelstvi, Praha, 1-432.

Johnson, W. T., H. Lyon, (1991): Insects that feed on trees and shrubs. Cornell University Press.

Jung T., Orlikowski L., Henricot B., Abad-Campos P., Aday A. G., Aguín Casal O., Bakonyi J., Cacciola S. O., Cech T., Chavarriaga D., Corcobado T., Cravador A., Decourcelle T., Denton G., Diamandis S., Doğmuş-Lehtijärvi H. T., Franceschini A., Ginetti, B., Green S., Glavendekić M., Hantula J., Hartmann G., Herrero M., Ivic D., Horta Jung M., Lilja A., Keca N., Kramarets V., Lyubenova A., Machado H., Magnano di San Lio G., Mansilla Vázquez P. J., Marçais B., Matsiakh I., Milenkovic I., Moricca S., Nagy Z. Á., Nechwatal J., Olsson C., Oszako T., Pane A., Paplomatas E. J., Pintos Varela C., Prospero S., Rial Martínez C., Rigling D., Robin C., Rytkönen A., Sánchez M. E., Sanz Ros A. V., Scanu B., Schlenzig A., Schumacher J., Slavov S., Solla A., Sousa E., Stenlid J., Talgø V., Tomic Z., Tsopelas P., Vannini A., Vettraino A. M., Wenneker M., Woodward S., Peréz-Sierra A. (2015): Widespread Phytophthora infestations in European nurseries put forest, semi-natural and horticultural ecosystems at high risk of Phytophthora diseases. Forest Pathology 46: 134-163.

Jung T. (2009): Beech decline in Central Europe driven by the interaction between Phytophthora infections and climatic extremes. Forest Pathology 39: 73-94.

Jung T., Nechwatal J. (2008): Phytophthora gallica sp. nov., a new species from rhizosphere soil of declining oak and reed stands in France and Germany. Mycological Research 112: 1195-1205.

Jung T., Blaschke H., Oßwald W. (2000): Involvement of soilborne Phytophthora species in Central European oak decline and the effect of site factors on the disease. Plant Pathology 49: 706-718.

Jung T., Blaschke H., Neumann P. (1996): Isolation, identification and pathogenicity of Phytophthora species from declining oak stands. European Journal of Forest Pathology 26: 253-272.

Karadžić D. (2010): Šumska fitopatologija. Univerzitet u Beogradu Šumarski fakultet, Beograd, 1-774.

Karadžić D., Milenković I. (2015): Prilog poznavanju parazitne gljive Inonotus nidus-pici Pilát uzročnika rak.rana na stablima lišćara. Šumarstvo br. 1-2, 15-29.

Karadžić D., Milenković I. (2014): Najčěść Inonotus vrste u šumama Srbije i Crne Gore. Šumarstvo br. 3-4, Beograd, 1-18.

Karadžić D., Radulović Z., Milenković I. (2014): Ganoderma vrste u šumama Srbije i Crne Gore. Šumarstvo br. 1-2, Beograd, 1-19

Karg, W. (1993). Raubmilben. Acari (Acarina), Milben Parasitiformes (Anactinochaeta). Cohors Gamasina Leach. 524 pp. Gustav Fischer Verlag, Jena, Stuttgart, New York 
Keifer, H.H. (1979): Eriophyid studies C-11. ARS-USDA, 24 pp.

Keifer, H.H. (1975): Eriophyoidea Nalepa. Injurious eriophyoid mites. In: Jeppson LR, Keifer HH, Baker EW (eds) Mites injurious to economic plants. University of California Press, Berkeley, pp 327-533.

Keifer, H.H. (1952): The Eriophyid mites of California (Acarina: Eriophyidae). Bull Calif Insect Surv 2 (1): 1-123.

Keifer, H.H. (1946). A review of the North American economic Eriophyid mites. J. Econ. Entomol. 39: 563-570.

Keifer, H.H. (1944): Eriophyid studies XIV BCDA, 33: 18-38.

Keifer, H.H. (1940): Eriophyid studies VIIII. BCDA, 29: 21-46.

Keifer, H.H. (1938): Eriophyid studies I. BCDA, 27: 181-206.

Maceljski, M. (2002): Poljoprivredna entomologija. Čakovec: Zrinjski, II dopunjeno izdanje

Maceljski, M, (1986): Current status of Corythuca ciliata in Europe. Bulletin OEPP/EPPO Bulletin 16: 621-624.

Malandraki, E., Petanovic, R., Nikolaos, (2004): Description of Two New Species of Eriophyid Mites (Acari: Prostigmata: Eriophyide) Common in Greece and Serbia, Agricultural University of Athens, Laboratory for Agricultural Zoology and Entomology, Iera Odos 75, 11855 Athens, Greece.

Mihajlović Lj. (2008): Šumarska entomologija, Univerzitet u BeograduŠumarski fakultet, Beograd.

Mihajlović, L. (2007): Metcalfa pruinosa (Say) (Homoptera: Auchenorrhyncha) nova štetna vrsta za entomofaunu Srbije. Glasnik Šumarskog fakulteta, br. 95, str. 127-134.

Milenković I. (2015): Diverzitet vrsta roda Phytophthora i njihova uloga u propadanju stabala u lišćarskim šumama u Srbiji. Univerzitet u Beogradu-Šumarski fakultet, doktorska disertacija u rukopisu, 1-240.

Mitrofanov, V.I., Strunkova, Z.I., Livshits, I.Z., (1987): Keys to the tetranychid mites (Tetranychidae, Bryobiidae) fauna of the USSR and adjacent countries. SSR, I.o.Z.a.P.E.N.P.T., Dushanbe, Donish: 224 p.

Murrill W.A., Burlingham G.S., Pennington L.H., Barnhart J.H. (1908): North American Flora, (Agaricales) Polyporaceae-Agaricaceae. The New York Botanical Garden, Volume 9, Part 2: 73-132.

Murrill W.A. (1903): A Historical Review of the Genera of the Polyporaceae. The Journal of Mycology 9 (2): 87-102.

Nalepa, A. (1910): Eriophyiden Gallmilben, Zoologica, 24 (61): 167-293. 
Overholts L. O. (1953): The Polyporaceae of the United States, Alaska and Canada. University of Michigan Press. Ann. Arbor, Michigan, 1-466.

Pegler D.N., Waterston J.M. (1968): Descriptopons of Pathogenic Fungi and Bacteria. Set 20, No. 194-197, Commonwealth Mycological Institute, Kew, Surrey, England.

Petanović, R. (1988a): Rhinotergum, a new genus, family Diptilomiopidae (Acari: Eriophyoidea). Acarologia (Paris) 29, 4, 319-323.

Petanović, R. (1988b): Eriofidne grinje u Jugoslaviji, 159 pp. Naučna Knjiga, Beograd.

Petrović-Obradović, O. (2003): Biljne vaši (Aphididae, Homoptera) Srbije. Poljoprivredni fakultet Univerziteta u Beogradu.

Pritchard, A.E., Baker, E.W., (1955) A revision of the spider mite family Tetranychidae.

Reeves, R.M. (1963): Tetranychidae infesting woody plants in New York State, and a life history study of the elm mite Eotetranychus matthyssei n.sp. Cornell University Agricultural Station Mem.: 99.

Rota, P.(1962): Osservazioni sugli Acari Tetranychidi dannosi alle piante coltivate ed ornamentali in Italia. Bollettino di Zoologia Agraria e di Bachicoltura, 4: 31-136.

Ryvarden L., Johansen I. (1980): A preliminary polypore flora of East Africa. Fungiflora, Oslo-Norway, 1-636.

Shi, A., Boczek, J. (2000): Studies on Eriophyoid mites (Acari: Eriophyoidea). XXXV. Bulletin of the polish Academy of Siences, Biological Siences. Vol. 48, No. 3. 241-254.

SmithMeyer M.K.P.S., (1987): African Tetranychidae (Acari: Prostigmata) - with reference to the world genera. Entomology Memoir, Department of Agriculture and Water Supply, Republic of South Africa, 69: 1-175.

Stalpers J.A. (1978): Identification of Wood-inhabiting Aphyllophorales in pure culture. Studies in Mycology, No. 16, Baarn, 1- 248.

Stamps D. J., Waterhouse G. M., Newhook F. J., Hall G. S. (1990): Revised tabularkey to the species of Phytophthora. CAB International Mycological Institute, Kew, Surrey, Mycol Pap 162: 28.

Stilinović, S. (1985): Semenarstvo šumskog i ukrasnog drveća i žbunja, Šumarski fakultet Beograd.

Strouts, R. G., T. G. Winter (2000): Diagnosis of ill-health in trees. Forestry Comission.

Tanasijević, N., Simova-Tošić, D. (1987): Posebna entomologija. Beograd: Naučna knjiga

Wagner T., Fischer M. (2002): Proceedings towards a natural classification of the worldwide taxa Phellinus s.l. and Inonotus s.l. and phylogenetic relationships of allied genera. Mycologia 94 (6), 998-1016. 


\title{
OCENA STANJA DRVENASTIH BILJNIH VRSTA U AKADEMSKOM PARKU U BEOGRADU
}

\author{
Katarina MLADENOVIĆ, Ivan MILENKOVIĆ, TATJANA ĆIRKOVIĆ-MITROVIĆ, \\ Ljiljana BRAŠANAC-BOSANAC
}

\section{Rezime}

U Akademskom parku u Beogradu tokom 2015/16 godine ocenjeno je zdravstveno stanje i urod semena drvenastih biljnih vrsta. Analizirane su ocene za svako pojedinačno stablo kao i srednje ocene svih stabala za svaki posmatrani biljni rod. Pregled zdravstvenog stanja je obuhvatio 126 stabala iz 19 rodova, a ocenjen je urod na 132 stabla.

$\mathrm{Na}$ terenu, tokom proleća i leta, obavljen je pregled krošnje, debla i korenovog vrata kako bi se utvrdilo prisustvo mehaničkih, fitopatoloških, entomoloških i akaroloških oštećenja. Izvršeno je vizuelna ocena zatečenog zdravstvenog stanja prema skali 1 do 5 , kao i ocena gubitka asimilacione površine i obezbojavanja za posmatrana stabla. U junu i julu izvršeno je ocenjivanje defolijacije a u avgustu dekolorizacija proučavanih stabala prema metodologiji ICP Forests

Analiza obilnosti uroda i semena je rađena na osnovu prilagođene Kaperove skale za predviđanje uroda semena u sastojini

Najvišu ocenu zdravstvenog stanja dobilo je pregledano stablo koprivića na kome nije utvrđena defolijacija i dekolorizacija. Nešto nižu ocenu $(4,8)$ ponela su stabla ukrasne šljive i sofore bez uočene defolijacije i dekolorizacije. Stabla gledičije su ocenjena sa 4,4 bez uočene defolijacije i dekolorizacije, kedra sa 4,3 bez dekolorizacije sa slabom defolijacijom, lipe sa 4,2 na kojoj nije utvrđena defolijacije već samo slaba dekolorizacija. Stabla javora, katalpe, jasena, ginka, koelreuterie, liriodendrona, borova, platana i hrasta su ocenjena sa 4,0. Stabla sa izraženim oštećenjima abiotičke i biotičke prirode su stabla kestena, breze, i crnog oraha. Prosečna ocena za sva ispitivana stabla u Akademskom parku je 4,0 .

Determinisani su sledeći uzročnici oštećenja: Phytophthora spp., Phellinus spp. Guignardia aesculi, Cameraria ochridella na kestenu. Lophodermium pinastri na crnom boru. Apiognomonia veneta i Corytucha ciliata na platanu. Erysiphe alphitoides na lužnjaku. Na stablima sitnolisne lipe Eucallipterus tiliae, Metcalfa pruinosa i Tetranychus urticae. Utvrđeno je da su štete od fitopatogenih gljiva značajnije u odnosu na oštećenja do kojih dovode prisutni insekte i grinje. Na većem broju ispitivanih stabala uočena su mehanička oštećenja koja su na adekvatan način sanirana.

Zdravstveno stanja pregledanih stabala drvenastih biljnih vrsta je bez utvrđenih značajnijih razlika tokom obe godine istraživanja.

Prilikom ocene obilnosti uroda utvrđeno je da od pregledanih 132 stabala 85 plodonosi. Plodonošenje u obe godine istraživanja nije se bitno razlikovalo, mada je bilo individualnih razlika u oceni plodonošenja. U najvišu kategoriju obilnosti uroda svrstano je 17 stabala sofore dok je jedno stablo ocenjeno je ocenom 2 u 2015 odnosno ocenom 1 u 2016. Od četinarskih vrsta, od ukupno 17 stabla atlaskog kedra, u obe istraživačke godine, 9 stabala je imalo obilan urod dok su u kategoriju 4 u 2015. godini svrstana tri odnosno u 2016. četiri stabla ove vrste. Od pet stabala platana samo četiri plodonose od toga tri obilno. Za jedno stablo javora i srebrne lipe urod je ocenjen najvišom ocenom 5, dok je stablo crnog bora ocenjeno sa ocenom 4 u obe godine istraživanja. Udeo lišćarskih vrasta koje su plodonosile a čiji je urod bio vrlo dobar, u obe godine istraživanja, je $60 \%$ dok su sa $21 \%$ zastupljene vrste kod kojih je izostalo plodonošenje. Kod četinarskih vrsta najvišu ocenu plodonošenja je dobilo 47,4\% u 2015. odnosno 43,0\%. u 2016. godini dok je urod izostao kod $10 \%$ stabala. 
Visoka prosečna ocena zdravstvenog stanja Akademskog parka je rezultat adekvatnih i redovnih mera nege i zaštite.

\section{EVALUATION OF THE CONDITION OF DENDROLOGICAL SPECIES IN ACADEMIC PARK IN BELGRADE}

\section{Summary}

In 2015/2016 health condition and seed yield of the dendrological species in Academic Park in Belgrade. Both scores for each individual tree and average scores for all trees within each plant genus under observation were analyzed. The health condition of 126 trees belonging 19 genera was examined while the seed yield was assessed for the total of 132 trees.

In spring and summer crowns, trunks and root collars were examined in order to identify mechanical, phytopathological, entomological and acarological damages, Visual assessments of the health condition as is were made as well as assessments of assimilation area loss and discoloration in the trees under observation. In June and July defoliation was assessed, while discoloration was inspected in the observed trees in August, applying ICP Forests methodology.

Analyses of the seed yield and its volume were performed using the adapted Kaper scale for forecasting seed yield within a stand.

The highest score was assigned to the single nettle tree examined, with no defoliation and discoloration identified. Slightly lower score (4.8) was assigned to the ornamental plum and Japanese pagoda trees, where no defoliation and discoloration were identified. Honey locust trees displayed no defoliation and discoloration and achieved a score of 4.4., cedar trees achieved a score of 4.3 and showed slight defoliation but no discoloration and lime trees received a score of 4.2 with no defoliation and low discoloration identified. Sycamore maples, catalpas, ash and gingko trees, golden raintrees, tulip poplar, pine, plane and oak trees scored 4.0. Horse chestnut, black walnut and birch trees displayed visible damage of both biotic and abiotic nature and origin. The overall average score for all trees examined in Academic Park equals 4.0.

The following causes of damage in injuries were determined: Phytophthora spp., Phellinus spp. Guignardia aesculi, and Cameraria ochridella in the chestnut trees; Lophodermium pinastri in the black pines; Apiognomonia veneta and Corytucha ciliata in the plane trees; Erysiphe alphitoides in English oaks; Eucallipterus tiliae, Metcalfa pruinosa and Tetranychus urticae in small-leaved lime trees. It was established that the damages caused by fungal pathogens are more significant than those caused by the present insects and mites. In a large number of trees examined, mechanical injuries were observed, which were adequately treated.

There were no significant differences in the health condition of the dendrological species examined during the two years of research.

Upon assessment of the seed yield volume, it was found that out of the total of 132 trees examined, 85 trees were fruit-bearing. There were no significant differences in fruit bearing between the two years of research, although there were different scores at the individual level. Seventeen Japanese pagoda trees were ranked within the highest-score category, while only one scored 2 and 1 in 2015 and 2016, respectively. Among conifers, the Atlas cedars were the largest in number with the total of 17 trees. In each year of research 9 trees had high volume yields, while score 4 was assigned to three trees in 2015 and thereafter to four trees of this species in 2016. Out of five plane trees four were fruitbearing, three with high volume yield. A single sycamore maple tree had a high volume 
yield over the period under observation as well as a silver lime tree, so these two were classified into category 5 - very good. A single black pine tree scored 4 both in 2015 and 2016. For all deciduous species with large number of trees the yield was very good - about $60 \%$ - in both years of research. About $21 \%$ of deciduous trees bore no fruits. In conifer species, $47.4 \%$ of trees had the highest score in 2015, while in 2016 their share decreased to $43.0 \%$. About $10 \%$ of conifer trees bore not fruits at all.

The high overall average score for health condition of Academic Park was a result of the adequate care and protection measures taken on an ongoing basis. 